\section{DIALOGO}

Multidisciplinary JOURNAL
This paper was presented at

The Annual Virtual International Conference on the Dialogue between Science and Theology (DIALOG0-CONF $2020 \mathrm{VIC}$ ) held online,

from November 3 - 12, 2020

\title{
The Melting point: How is the World reshaping under pressure nowadays?
}

\author{
Lecturer Rev. Cosmin-Tudor CIOCAN, Ph.D. Assist. Prof. Osman Murat Deniz, Ph.D. \\ The Faculty of Theology, \\ 'Ovidius' University of Constanța, \\ ROMANIA \\ Department of Philosophy and Religious Studies, \\ Çanakkale Onsekiz Mart Üniversitesi, \\ Çanakkale, TURKEY \\ cosmin.ciocan@univ-ovidius.ro \\ osmanden i z@gma i I . com
}

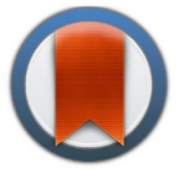

\author{
Assist. Prof. Filip NAlaskowski, Ph.D. \\ Faculty of Educational Sciences \\ Nicolaus Copernicus University in Torun \\ POLAND
}

Fi I i p. Nalaskowski@umk.pl

\section{ARTICLE INFO}

Article history:

Received 24 August 2020

Received in revised form 19 October Accepted 25 October 2020

Available online 30 November 2020 doi: $10.18638 /$ dialogo.2020.7.1.17

\section{Keywords:}

religious pluralism; dialectics; values changes; social innovation; Covid-19; social engagement; infection; infectious disease; riots; curfew; pandemic; outbreak;

\section{ABSTRACT}

We are witnesses to a major reshaping of our world: the World and our lives as we used to know are ending and they are reshaping constantly and drastically under pressure. Everything we knew about this world, our old habits, values, human rights, ethical patterns et all. These days, since the pandemic outburst, I saw the perceptions we have/ had on religious impositions and requirements changing for an unprecedented behavior and inconsiderably reshaping religious phenomenon could have ever think of. With the title taken from the topic of this volume, Inspired by the conference titled, we have tried to envision the actual human environment through the ongoing pandemic that revolutions the entire human society in a way we had never considered as possible and so that we will not recognize in a year or so. Following the Philosophy of Dialectics and seeing a larger number of possibilities beyond those that were revealed to us in most obvious ways, we wonder thus, what makes us, in fact, do these changes - is the pandemic itself and its requirements or is it just US, humans, that were long longing for a change, a motif to do it all new again? It is though a human-divine desire to anew all from time to time and seek a reboot to all wrongness that grows in the world.

(c) 2014 RCDST. All rights reserved.

Copyright (C) 2020 Cosmin-Tudor Ciocan, Osman Murat Deniz, Filip Nalaskowski. This is an open access article distributed under the Creative Commons Attribution License, which permits unrestricted use, distribution, and reproduction in any medium, provided the original work is properly cited.

Citation: Ciocan, Cosmin-Tudor, Osman Murat Deniz, Filip Nalaskowski. "The Melting point: How is the World reshaping under pressure nowadays?" DIALOGO, ISSN: 2393-1744, vol. 7, issue 1 (November 2020): 197-210. DOI: 10.18638/dialogo.2020.7.1.17 


\section{INTRODUCTION}

"Behold, I am making all things new." (Revelation 21:5) - this is quite a scary and undesirable statement coming from the divine part and regarding the world as we, humans, got used with. It happens with it for several occasions though [considering Noe's event, Christ's appearance or Apocalyptic events or on a small scale in many other occasions], and we are witnessing as such nowadays too, amid Covid-19 pandemic. Liked or not, a tremendous change occurs nevertheless, but we surely need to understand why is it happening so that we can assume what is happening. In order to have this figured out we need to establish the steps our world walked and the stages of this outbreak and how it evolved at least until today (November 2020). But let's start with the beginning.

Starting in December 2019 in Wuhan, Hubei, China [1] and shortly after this infectious disease caused by acute respiratory syndrome coronavirus 2 (SARSCoV-2) broke out in an ongoing pandemic. The starting point of this pandemic in Europe, America and then globally was in February-March 2020, beginning with Italy where the first case was reported in January 30 and its spread escalated rapidly, but especially frighteningly. As of 13 March 2020, the World Health Organization (WHO) considered Europe the active center of the pandemic[2]. On 19 March 2020, Italy overtook China as the country with the most deaths ( 3,405 by then)[3]. By 26 March, the United States had overtaken China and Italy with the highest number of confirmed cases in the world.[4] And so on and so forth; one after another many different countries from both continents, European and American, negatively 'fought' for the pall position in this pandemic. Either it was for the most infected country, the highest curve of rapidness, the largest rate of deceased, the largest number of daily reported cases or deaths, confirmed cases, healed cases or even the first City with the largest number of deceased by Covid19 [New York with more than 20,000 deaths in October or before that for months][5].

There are so many and various data to process right now and it is very useful to simply measure them for the moment. A time to learn from them will come eventually and new reports and conclusions will become our priority after lowering the threat. But no matter what angle we have while looking at this outbreak, regardless what specific impact of it we want to analyze, the ground fact is the same: it all started and escalated so rapidly throughout the entire world that no region was possibly hided from its haze.

\section{STAGES OF SOCIAL 'WELFARE' AMID PANDEMIC}

\section{A. First stage, Imposing measures}

For at least three months, February to May, the entire world had an ascendant curve on anything regarding this coronavirus: infected, daily new cases, acute to severe cases, deceased.[6] That was a period of irrationality, of fear in which we have built frightening scenarios, when the cases of infected grew so rapidly that all Governments could do at that point was to act in kind as humans, individual or species: protect what's left, try to preserve the remains while taking drastic measures aimed at containing the disease. That stage was in fact governed by the afraid of extinction no one spoke of, considered as a possibility, everyone denied it as even being feasible, but, deep inside, everyone saw it before their eyes. Under the influence of this emotion that has the most effectiveness and the largest amount of dopamine, and thinking that, even if the species as a whole might survive this threat as individuals, regions or even countries might not be that 'lucky', 
each and all the national governments took several measures to ensure our survival as many as it could be possible. For this first stage it was not concluding or considerable what other changes their decision provoked, what other negative impact will occur aftermath, or what set of human rights are disputed by the impositions. It was the stage of 'acting before thinking', a stage of 'first aid' that is always characterized more by emotions and less by reasoning, fear and anxiety mostly over other human emotions; This fear of human disaster stimulated in every person a behavior of 'flight-or-fight', entering a stage of self-preservation and disregarding everything taught before. It was brief, but strongest, thus the measures that have been taken overpassed the unimaginable of humans: constraints and limitations of rights were imposed as in a totalitarian and absolutist atmosphere - all in a beneficial and protective note. The main idea of this stage was to protect life itself by any means necessary and with all costs. What would be those measures imposed by each State in the World as precaution against the spreading of Covid-19 in the most dangerous and uncontrollable way? Strict surveillance measures are being enforced at airports, seaports and border crossings to prevent the disease wide-spreading into countries/ territories which either share a border with or are located in the neighborhood of most affected countries. Lockdown within countries or just regions were also immediately effective. It is very important to understand two things about this first stage: a) the need to respond rapidly to the Covid-19 crisis has led to the adoption of emergency measures and $b$ ) the measures adopted are allowing exceptions to the main principles of European and Global laws while most States that gave these impositions were previously declared as 'democratic'. We have discussed a) while saying that everything was scarcely considered in perspective, with analytical depth and consideration of all domino effects generated by these measures. Also, we need to take special care on b), but we will do this later on, when learning about second stage.

Whereas the spread of coronavirus outbreak [Sars-CoV-2][7], developing into a global pandemic situation, the governments everywhere have declared a 'state of emergency' to stop the spread of the pandemic as much as possible. What are the human/legal rights that you have faced as being violated under this pretext by the State? I mentioned also the 'legal' rights as if there are local constitutional lawful rights that are also violated by police enforcement or so. And the people that was 'protected' by the impositions against their will, but also in a state of low awareness, have reported these rights violations: the right of free movement, the right of congregation, the right of equal treatment (for businesses and shops), the right of schooling for children...

This is a stage of pure action[8], mostly without considering the effects of these actions themselves or even without caring about them at all, and the main reason of this course of action was always a greater good. Thus, everyone was banned from public places, workers redraw from work, children from schools, and all these increasingly dramatic measures while the spread of the deadly contagion filled the hospitals at a level that doctors had to take another unprecedented decision, who lives or dies. 'In normal conditions' - a phrase that lasts on everyone's' lips this year - they shouldn't have to make this decision, but now they are forced to do it so everything officials do is to protect the last barricade against this deadly virus, medicine. "We need to buy time for the medical research to find a cure" are the worldwide declarations, moreover since most countries, even those advised to face a pandemic have not been properly prepared and equipped to respond to such a biological 'attack'. It is pointless to say that 
these so-called 'predictions' or 'foreseen messages' from previous years were taken as the complot of some 'secrete society'[9] against humanity by those in favor of the 'conspiracy theory'.

As proved by facts, there were so many collateral drama that have risen precisely of these first stage impositions that people took a step back in this 'game' of survival and started another stage. As a result of COVID-19, many companies moved to remote working in response to lockdown measures. Now many businesses have redesigned their offices, to account for social distancing, attempting to give employees the confidence to return.

\section{B. Stage two, Reconsidering priorities}

How can this interference of the Public authorities with your right be regarded, justified, or on the contrary, denied and fought against? Many people were directly affected by the pandemic in the first stage, but even more indirectly, through the crises that followed the impositions took 'in their interest'. Thus questions like 'what is worse...', or sayings like 'if the pandemic won't kill us, the hunger will do it for sure' gave people a brief moment of thinking and reconsidering their position regarding those impositions of the first stage. Not seeking or caring about the 'greater good', common people took that step back and leave Governments in off-side, drawing a line in this 'reality' and escaping to the other side of it. This second stage was established around April-May 2020.

"It is no secret that the lockdown and the health crisis will have major economic consequences. To avoid companies collapsing like dominoes, especially the most vulnerable already facing cash-flow problems, the government has adopted a three-pronged response, encompassing tax, employment law and direct support for companies."[10]

\section{Stage three, Riots and disobedience}

Itwasthisbriefstagetwo, of reconsidering our position in regard to the actual threat and the waves that are caused by the initial measures, which started stage three, riots and disobedience. This stage of reaction was initiated also by fear, by uncertainty, but this time not of the damages that could be caused by the Covid-19 pandemic, but of all other major crises that are raised by the impositions against this pandemic.

There is an interesting case of events in this stage of denial, consist of the wave of speeches by supporters of conspiracy theories. At a time when the development of the epidemic was weakening, when the growth curves started to flatten, a movement of people questioning the danger of COVID-19 emerged. These people went out on the streets with the slogans 'Stop PLANdemic'. According to the demonstrators, there was no pandemic, or it was much weaker than what the authorities suggested.

A large proportion of the demonstrators were those in favour of conspiracy theories. The scenario they presented was as follows. There is no virus, or it is just the common flu. It is not dangerous, or in any case not more dangerous than the flu. The measures taken by governments are not really designed to protect the population and prevent the virus from spreading, but to restrict civil freedom. Societies horrified by the Sarc-Cov-2 threat will not protest against the actions of the authorities without seeing their freedom threatened. What restrictions are we talking about? Various ones. First of all, the difficulties connected with everyday life. The obligation to wear masks and disinfect hands, obligatory temperature measurements. Restrictions on traveling abroad, on the functioning of shops, cinemas, restaurants, 
attending religious public services, etc.

Secondly, more severe restrictions on civil freedom. Prohibitions on gathering in a larger group - is one that mostly bothers people due to its social impact on individuals. Obstacles related to the holding of elections (presidential, local parliamentary elections), sometimes involving their postponement or cancellation. Surveillance activities are carried out by governments, such as registering and controlling infected persons, tracking their contacts to identify the spread of the disease. Finally, literal deprivation of liberty, such as when an infected person or a person suspected of being infected is placed under quarantine - then there is a ban on movement and the need to break the rhythm of the previous life.

Surely, the state of the pandemic restricts our free functioning, part of our civil freedom, but it is entirely a planned action of a global government? In the opinion of the opponents of PLANdemic, yes, it is. They claim that the entire action of the authorities is aimed at making societies fully subordinate and facilitating their control. Supporters of this theory are keen to cite the case of the United States, where, after the 9/11 attacks, horrified American society did not protest when the President and Senate adopted further legal acts that strongly restrict the freedom of US citizens, while at the same time strengthening mechanisms and institutions of social control.

For most societies, voices such as those above were a rather marginal part of the main political discourse. The anti-PLANdemic demonstrations gathered several hundred people at most, paradoxically increasing the risk of infection in this group. It is not entirely clear whether the personal experience of Covid-19, or the successive statistical increases in the incidence of the disease, has made these voices very quiet, and today not many people question the existence and danger of the virus.

\section{Stage four, Relaxation to re-building economy. Reopening businesses}

Many officials were amazed by the side effects of the measures initially taken. At this point it was of the officials that took a step back and reconsider the catastrophic effects of their impositions over the entire society. 'Maybe we have exaggerated a bit', some of them eventually agreed and with this awareness a new process began, that of relaxation. It was a stage of awareness, when, balancing the harm caused by the medical pandemic with the damage caused by the restrictive measures, it was found that the latter are much more devastating and deeper for humanity than this pandemic could do. It is clear to everyone that the economy and businesses keep the whole society efficient and moving, in other words alive, and if some measures, no matter how well-intentioned or for any reason, are set up, make the interconnected system of businesses and other stakeholders to collapse so that humanity is doomed even if it comes out fully alive from this pandemic or other uneconomic crisis.

"As the latest data shows, the rate of deaths, new infections and hospitalizations appear to be slowing in some parts of the country and most states are making plans on how to restart their economies, leaving restaurant owners, in particular, with a tough choice: Open at the risk of a resurgence of the invisible contagion formally known as COVID-19, or wait until the scientists reach a consensus that it's safe."[11] It was during the summer of 2020 that most countries tried to reboot their economy by having all the previous considerations took in practice and give up the strictness of the measures so that the population could gain some economies for their daily needs. Knowing the severe effects of previous major economic crises ["the Great Depression" back in 1929-33[12] 
or the most recent one in 2006-8 in USA, Europe and beyond] over the population politicians get back into senses with these restrictions and forged the Media's news about Covid-19 impact and spreading so that it could allow everyone to get back to work. 'People need to get back work, with safety measures of course, but still they need to start up the economy nonetheless' it was the most heard motivational speech of politicians and officials before the summer, late May and early June.

Now many businesses have redesigned their offices, to account for social distancing, attempting to give employees the confidence to return. Restaurants have moved outside, in the streets, to regain clients, hotels and touristic stakeholders lowered their prices while considering all the social safety measures in regard to their employees and for the clients as well. From the other side of this picture, many people who found themselves unemployed overnight amid pandemic for obvious reasons [small businesses closed, factories reducing their numbers or go bankrupted, et all], went on to professional retraining as seasonal workers to finding easy and quick paid work. Thus, in mid-August most businesses were opened and fully functional on most economic sectors. Even with all the measure of precaution taken the rate of reopening was less than half, meaning that it is too low to place everyone far from bankruptcy or to get rid of mortgage. "There is a question: are we going to make money given the new social distancing guidelines?", was the main issue most small business have asked (mostly to themselves). "Disparate reopening plans are going to continue to hurt small businesses, as they are particularly vulnerable to the economic impact of the coronavirus due to a lack of financial resources as compared to larger companies. With fewer resources available, many small businesses likely have not developed comprehensive response and recovery plans yet."[13] Still, this was a step forward in recovery moreover since new infection rates drop during the summer, or at least so it seemed...

What also characterizes this stage is hope, hope that everything is now going back to 'normal', hope that we can adapt to the new conditions so that we can live our lives as we used to know it. "I think we'll be OK, but it is NOT SUSTAINABLE for the long haul: we need to open up... We've survived the LA riots, we survived 9/11, we survived 2008... I think overtime we'll adjust, we figure out how can we get back to as close to normal as we possibly can?"[14] It was either working from home as in IT or School sectors, confining serving food on Take-away format, working in more shifts in industries or installing new costly gears and expensive improvisations just to stay on tracks and earn some money. One way or another businessman found a way to continue working while seasoning all with safety measures. Pernice Ryan, head of three restaurants in suburban Atlanta, says "he's been scouring the open market for masks, gloves and hand sanitizer, and rejiggering floor plans to do what most savvy restaurateurs would normally consider illogical: creating more space for fewer people."'[15]

\section{E. Stage five, Pandemic elevation and new impositions}

With this 'breath offresh air' we witnessed many countries in Europe considering taking one after another relaxation measures to attract clients and restart business. So was the case with Greece, with Italy - the most affected country by Covid-19 pandemic in Europe - any other similar that have majority of businesses based on tourism and stakeholders. They considered reopening their borders for aliens very quickly and with only few, basic rules [e.g. a statement on 
one's own responsibility at first]. "The GECS report predicts two scenarios for finance professionals to consider when planning for reopening. The first is that there is no significant second wave of virus infections leading to renewed lockdown measures and an inevitable return to recession. On this assumption, we expect the global economy to recover in the second half of this year and through 2021. However, even in this rosy scenario, most advanced economies are not likely to reach end-2019 levels of output until at least the second half of 2022.

The second scenario is that of a second wave. An increasing number of infections in Europe, South America and many U.S. states has raised fears of a second wave of the pandemic that leads to renewed lockdowns in a significant proportion of the world."[16]

After officials all over the world, notorious as Donald Trump, Boris Johnson and many others urged people to come out of 'the hibernation', leave lockdown and get back on the streets without masks and other additional precaution than usual, ideas also doubled by the statements of some specialists in the medical field we witnessed a second, steeper and more savage wave that hits the population. We see really serious spikes in the infection daily reports all over the world and people are wondering if it was because of these 'encouragements' that a second response-wave occurs quicker and stronger.

\section{F. Stage six, Mistrust and more disobedience}

Being afraid of both scenarios, like Hercules once between Scylla and Charybdis, humans for most of the population redraw its trust from medicine, from its 'final' word on the matter and get more disobedience than before. At this level there are in public circulation so many and varied messages about the 'real face' of this pandemic than we can even imagine. 'Specialists' in immunology urging people to go about their daily tasks without a mask and without being afraid because this is the only way they can build their immune system, confronting it directly and seeing what effects it has on them - as if we should risk and bet our lives to this confrontation. It is 'viral' the new approach two doctors from Bakersfield came up with regarding the wear of masks and our healthy. Drs. Dan Erickson and Artin Massihi from Accelerated Urgent Care held a press conference at their Coffee Road facility on April 22. They claimed their COVID testing proved the novel coronavirus had spread widely in the region and was thus less of a concern, but public health experts say they were jumping to that conclusion based on an unrepresentative sample.[17] These Bakersfield doctors was exactly what many stuck-at-home Americans and beyond wanted to hear: COVID-19 is no worse than influenza, its death rates are low and we should all go back to work and school. Against everything we were thought about previously on how to avoid Covid infection they state that in reality "COVID-19 is being made out to be more dangerous than it really is"'[18].

"When you wear gloves that transfer disease everywhere, those gloves have bacteria all over them. "I'm wearing gloves," not helping you... Your mask that you're wearing for days, you touch the outside of it, COVID, and then touch your mouth, this doesn't make any sense. We wear masks in an acute setting to protect us, we're not wearing masks (right now). Why is that? Because we understand microbiology, we understand immunology and we want strong immune systems. I don't want to hide in my home, develop a weak immune system, and then come out and get disease. We've both been to the ER through swine flu and through bird flu, did we shut down for those? Were they much less dangerous than COVID? Is the 
flu less dangerous than COVID? Let's look at the death rates, no it's not. They're similar in prevalence and in death rate."[19]

'This is a serious infection and no amount of lifestyle intervention will make you invincible,' says Dr Jenna Macciochi, an immunologist at the University of Sussex, whose timely new book Immunity: the science of staying well is out on April 16th. [20] Other scientists say that lockdown and social distancing could make our immune system weaker; "Sunetra Gupta, professor of theoretical epidemiology at the University of Oxford, fears intense social distancing could actually weaken immune systems because people are not exposed to germs and so do not develop defenses that could protect them against future pandemics."[21]

You don't have to be an expert in anthropology or sociology to foreseen how these statements can start a riot, mass disappointment in the State impositions and civil society dismemberment and destabilization. Now the question is who can possibly take advantage of this state of things in our society? Is it about 'divide and conquer'? And then again who could 'order' such stepping into the limelight of some medical staff and to disavow the whole scenario on which the Covid19 spreading streak is being built, making them the promoters of a new scenario, which already proved to be harmful and futile in phase 4 and 5 ?!

The pandemic period has changed the agenda of the world so much that many issues became unspeakable. It seems that it will continue to be a predominant topic of economic, political, social, cultural, and religious discussion for some time. Topics discussed in the medical world just before pandemic were whether vaccines are effective in controlling disease, whether different recommendations in the field of healthy nutrition and alternative medicine practices are required. The increase in deaths due to Covid-19 pandemic has completely changed daily life as stated above. To prevent its spread, all countries have had to take extremely strict measures at the expense of stopping economic and social life almost wholly. The world economy is negatively affected by pandemic and pandemic measures in terms of both supply and demand. The slow-down or even standstill of economic life impacted the working life strongly and pandemic is presented in the financial circles as a major threat to employment. In this context, employment levels are expected to decline notably further over the pandemic times around the world.[22] Nevertheless, though every non-essential businesses and several branches of economic activity have been closed by virtue of restrictions and social distancing rule, some businesses, such as those in outdoor recreation and those working from home especially via internet without huge investment and social interaction, thrived.

As it turns out, the crisis caused by Covid-19, unlike the others that plagued the world, is completely human-oriented. The main factor that can help end this pandemic process is requiring people to strictly follow the hygiene rules along with mask usage, and as a precautionary measure to keep a safe space between themselves and others. In order to provide the necessary social distance, unless it is necessary, work processes in different business sectors and all kinds of teaching and training activities must be carried out through digital operation using online-remote working systems for a certain period of time.[23] "What is becoming clear is that the post-Covid-19 new normal will be different. Boston Consulting Group's view is that "comfort with remote work will reshape our future workplace," where flexible work arrangements will increasingly be the norm."'[24] Looking on the bright side, the possibility and success 
of remote working and distance education have been widely experienced and fully tested. In this process, the digital world is used effectively but we should learn to use it competently.

There is a rich literature on the effects of dreaded diseases in human history. In this literature, it is recorded how diseases affected both Western and Eastern civilizations. For instance, in the 14th century, the Black Death, the plague broke the Malthusian stalemate[25] and on the other hand it was the driving force behind the restructuring of European communities; genetic diseases changed the fates of the British, Spanish and Russian royal families over the past two centuries and played an important role as one of the factors resulted in the rise of Lenin, Franco and Hitler to power. In the last hundred years, we've seen "how increased opportunities for diseases transmissions have decimated populations, created panic, and fostered discrimination." We are painfully aware of how a contagious disease can lead to large-scale social and political changes and how it creates and worsens social tensions. In the past, diseases played a fundamental role in the spread of colonialism on African and American continents, and they forced the Irish people into mass migration due to demographic pressure and hunger; In the future, an unexpected disease can make the same effect in other places and in other ways.[26] Today, thanks to Covid-19 the importance of urban planning accord with fighting against disease and need for housing that observes public health is comprehended. In the first place, small towns across the world have been hard-hit by the pandemic, but it turns out that "small towns have the advantage of being more nimble and responsive to crisis than cities, largely because they have fewer regulations and more opportunities to be creative about problem-solving."[27] A specific increase in the fear of pandemics and lockdowns may prompt migration out of big cities and people flee cities for the suburbs. The "cities might look much as they do today - just a little less crowded, with a little more local open space, and with more of the resources they need to support themselves on the doorstep."[28]

Coronavirus pandemic, based on the death toll, is actually an epidemic with little effect than its historical counterparts. While it is difficult to predict how many people will lose their lives in total, it is possible to say that it will not be as deadly as the great outbreaks in history. This, of course, does not change the fact that the global economy will suffer severely because of measures to prevent the spread of the virus. The Covid-19 is considered the biggest global disaster since the Second World War.[29]

It is evident that Covid-19 will compel many people to change the way they do things. However, it might be complicated how they will make their lives different. The pandemic periods have been destructive for everybody who have lost their parents, children and friends or got into a jam, but they have also caused notable opportunity and innovation.

Major infectious diseases have changed the course of the world throughout the history. Porphyria and hemophilia influenced political life in England, Russia, Spain, Germany, and the United States; The Irish Potato Blight caused waves of immigration that changed the policy of the United States. Cholera promoted taking hygiene measures, helped the development of nursing profession and caused the discovery of rehydration therapy. Smallpox led to the invention of the vaccine that allows the elimination of the disease. Bubonic Plague improved quarantine measures and attenuated vaccines were the result of outbreaks of tuberculosis. Syphilis opened the door for cure through chemotherapy. Malaria and Yellow Fewer formed the 
basis for vector control. However, the two epidemics that engulfed the world, The Great Influenza and HIV/AIDS, have not been completely overcome yet.[30] It seems that the Covid-19 pandemic is a candidate for being the third quite a long time.

It was not foreseen that so many people would be affected. We had some very interesting observations in the process. The most shocking of these were the high mortality rates in the developed capitalist countries of Western Europe and North America. Pandemic hit the big cities of the big countries. Socio-economically disadvantaged groups living in large cities were the most affected. Anti-racism protests over the murder of a black civilian killed by police brutality in the United States have emerged on the backdrop of the COVID-19 pandemic. In this respect, it has been an expression of the disproportionately disadvantaged situation that poor people are living in. [31]

There are important reasons why death rates in developed capitalist countries of the West are high. As with other similar diseases, the Covid-19 affects people with chronic diseases and is more deadly in those with heart condition, hypertension, diabetes, and chronic lung diseases etc. As age increases, such chronic diseases increase, so the mortality rate in the elderly population is higher. Therefore, there have been too many deaths in aged care homes, especially in Italy. Turkey's population pyramid was the advantage of being young. On the other hand, being in a culture that cares about the elderly has provided an undeniable advantage. Those who are ill have to be hospitalized and have access to proper care. The countries with appropriate number of hospital beds and those having the essential supplies and devices such as inhalers and those have been able to coordinate between hospitals have succeeded. Death rates were lower in countries with high laboratory capacity.

Pandemic has closely influenced politics in all countries. Pandemic had significant bottlenecks since the beginning. There were significant problems in the diagnosis, treatment, and control of the infection. There were areas where science could not respond quickly, and the empty spaces were quickly filled. In this context, a drug has been of interest to politicians. Hydroxychloroquine was the most discussed drug in Coronavirus-19 disease. President Trump has directly declared that the drug is so effective. What the scientists say about it? How were the studies? Without the opportunity to answer such questions, a polarization occurred between those on the hydroxychloroquine side and those against it. In the future, probably, this drug will be remembered as an example of the polarization of science. There are many lessons to be learned from this crisis.[32] According to the virologist Guido Silvestri, professor at Emory University in Atlanta, we should "invest in science, at all levels, and protect it from scoundrels." and "support education in science and culture in general, starting from schools." Serious information, without catastrophism and sensationalism, must be subject to inquiry.[33]

Mostimportant lesson Covid-19 pandemic must have taught us the importance of science in the first place. Hearsay information, superstitions and fake solutions quickly lost their importance. Galilee, the Italian astronomer, taught us that no power can stand in the way of knowledge based on solid foundations. Knowledge is power that is what the philosopher Francis Bacon said. Studies, works and devoted efforts of health care providers, being in solidarity with each other under the guidance of science, has been our most important assurance.

Corona is not just a health crisis. It is also an economic and social crisis. In this crisis, some people think about their patients, 
while a much larger part thinks about their livelihoods. It is very important that people who feel more economically comfortable allocate a share of their personal budgets to social assistance.

Sociologists have not been able to reach consensus on where society and therefore civilization began. Those supporting the classical sociology theory say that civilization began with the distribution of more food because of the development of agriculture. However, the findings at Göbeklitepe excavations suggest that the need for worship began before the beginning of the settled life. a group of sociologists say that civilization begins with the rituals of social believing, that is civilization sprouted from religion, before agriculture. Moreover, Margaret Mead, the American anthropologist, has a very good explanation: Mead says the first sign of civilization in an ancient culture was a femur (thighbone) that had been broken and then healed. Covid-19 shows us what our civilization is capable of and where it is fragile. It is up to all of us to look outside our own situation and do whatever we can and help by delivering our thoughts, even if we cannot reach out to the one next to us.[34]

Developments shows that the whole world is going through a period of depression. The crises created by the periods of depression have always brought new fluctuations. During this period, a surge began and continues. Therefore, as seen in other fluctuations on the world scale, a number of social upsets will occur with the process we are experiencing and a new social balance will be found by forming a new order in a certain period of time. The question of what the new normal will looks like includes some question marks and obscurities.[35]

\section{G. Final stage - for now...}

The phase that emerged from the reappearance of the autumn increase in infections was clearly different from the earlier stages. It is a period of simultaneous calm and panic.

The earlier stages have slightly dormant our caution, gave us a lot of confidence, self -survival. On the one hand, people already knew what the epidemic was, what its symptoms were or expect to find out about its development. They got used to it in the media and the mouth of politicians. On the other hand, they have already got used to some of the restrictions and limitations. A lot of faith in improving the situation was given to us by the world of science. There are 150 laboratories in the world working on the vaccine, 30 of which may already be on the market in the coming weeks, months. Doctors have ways to treat Covid-19. Governments are prepared for the disease - there is equipment, staff, medicines. We are close to overcoming the virus. After 9-10 months, the pandemic is losing - just a moment more left.

It is also important that Covid-19 existed in the general public consciousness, but not necessarily in 'ours'. At the beginning of the pandemic, IT had 1 infected in a million, then 1 in 100000 citizens of the state. The media reports at first sounded ominous, but we got used to it. We are not personally affected. Even when it appeared in our town, it was not yet our personal problem, not that of our family. When statistics showed that mortality was not exceptional, only for the elderly and the sick, the absolute majority of people slept peacefully. What is more, the governments, some authorities calmed the residents down - the apocalypse is not coming.

Everything started to change in the autumn. Suddenly, there were huge increases in the incidence of disease. 
Something that was supposed to end not only continued but was growing stronger. Those whom we know began to get sick. The virus came closer and closer, and it turned out that it existed and was next door. Then, everyone knew personally someone who was ill, who was under quarantine. Finally, someone who died of it. The virus became real as it creeps in among us.

So far, the reassuring tone of the media has become less reliable. Information about the return of the lockdown. And increasingly worse reports from the front line of the fight against the disease - from the health service. The capacity of hospitals has slowly become exhausted. There was a shortage of places for patients. It turned out that lifesaving respirators might not be enough. The number of medical staff also turned out to be too small given the growing needs.

A new stage of panic caused some people to start to stock up on food and water, not like at the beginning of the pandemic, but to secure private medical equipment. Cheap medical devices capable of supplying oxygen, cheap respirators, and available supplies of oxygen in bottles were slowly disappearing from shops, from the Internet. While six months ago it was a niche product, which was only of interest to the medical industry, now private homes are being transformed into substitutes for private hospitals.

Societies have begun to move from 'private prevention' to 'private treatment'. And from 'the virus is there' to 'the virus is here'.

\section{CONCLUSION}

The psychological impact of fast, deadly spread of the new coronavirus Sars-CoV-2 has given us fear like as near to extinction and that caused drastic, unprecedented measure of precaution. Aftermath we have realized that in order to survive we need to get back to our daily chores and duties regardless of the Covid-19 menace. However, the new the state of vigilance and caution did not last long, and in some places, it was not even established due to the psychological blockage of 'believing' in such reality of the threat of this pandemic, considered either as only presumed, or at least exaggerated in effects and danger. People went to the streets where officials did not get aware of the inefficiency of precautionary measures to ensure the safety of the population while leaving the economy to dye. The easy way of assuming relaxation and reopening society, even with some social measures, has risen doubts to many that all these scary scenarios constructed in Media News along the 2020 are even realistic and true and they should not be entrusted with our wealth damaged. As easily can be foreseen pandemic social spreading didn't get a pause to let us earn money or trust, instead it took advantage of our ego and this lack of confidence in medical research/advices costs us the new wave of corona-spreading, more rapidly and acute then the first one. Now we stay aside and watch it grows among us, closer and closer to anyone. In the beginning, it was merely a rumor among some researchers in immunology, now it's a fact that it/ pandemic will be 'over' when most of the population will get in touch directly with it [i.e. coronavirus]. Thus, it was surely and clearly foreseen that eventually, we all have to face its rage and get on a list, either of those immune, recovered, or deceased, but anyway infected. In conclusion, how we characterize pandemic of 2020? Fear and despair, then hope and courage, followed by another episode of rising pandemic, then fear, and hope again. What didn't kill us makes us stronger, so we will figure out a way out of this and we definitely get rid of this eventually, of course not all of us... ?

At this juncture, we would say that nothing is yet 'sure' and we are walking on 
sand with all the knowledge we have on this pandemic. Consequently, it is up to each of us to write the end of this chapter, either taking into account of the safety caution measures - if we afford it financially until the 'end' - and thus still being here to tell the story by its bitter end, or making otherwise and researching what's coming next on your own skin.

\section{REFERENCES}

[1] "Timeline of ECDC's reponse to COVID-19", https://www.ecdc.europa.eu/en/covid-19/ timeline-ecdc-response.

[2] Fredericks B (13 March 2020). "WHO says Europe is new epicenter of coronavirus pandemic". New York Post. Retrieved 9 May 2020.

[3] "Coronavirus: Number of COVID-19 deaths in Italy surpasses China as total reaches 3,405". Sky News. Retrieved 7 May 2020.

[4] McNeil Jr DG (26 March 2020). "The U.S. Now Leads the World in Confirmed Coronavirus Cases". The New York Times. Retrieved 27 March 2020.

[5] It is more important to know the rates in these cases because if the number is scary, comparing to the population the rate is even worse. For example, we may report that the rate of confirmed COVID-19 cases is 100 per 100,000 population in NYC. That means for every 100,000 people living in NYC, there are 100 people diagnosed with COVID-19. https://www1.nyc.gov/site/doh/covid/covid19-data.page, Retrieved 7 October 2020.

[6] All the possible and knew data about Covid-19 are taken from https://ourworldindata.org/ covid-cases.

[7] Severe acute respiratory syndrome coronavirus 2 (SARS-CoV-2) is the virus strain that causes coronavirus disease 2019 (COVID-19), a respiratory illness. Gorbalenya, A.E., Baker, S.C., Baric, R.S. et al. The species Severe acute respiratory syndrome-related coronavirus: classifying 2019-nCoV and naming it SARS-CoV-2. Nat Microbiol 5, 536-544 (2020). https://doi. org/10.1038/s41564-020-0695-Z
[8] In spite of many comments of the current criticism, I won't characterize this period as a 'stage of restrictions' and not because it isn't but because that is not its motivational feature; instead fear and reaction to build safety is.

[9] This is not the place to advance and argue the declarations and suggestions of a conspiracy that was somehow proved by previous warnings about the possibility and imminence of this pandemic. Signals such as the movie "Pandemic", "Contagion" (2017), Bill Gates declarations about that in 2018 and many others who seemingly predicted the coronavirus pandemic. Retrieved from https://www.businessinsider.com/peoplewho-seemingly-predicted-the-coronaviruspandemic-2020-3, accessed April 2020.

[10] https://cms.law/en/fra/insight/covid-19coronavirus/exceptional-measures

[11] Bill Hutchinson, "Prospect of reopening amid COVID-19 crisis has some restaurateurs balking" in $A b s$ NEWS, 5 May 2020. URL: https://abcnews.go.com/Business/restaurantsmull-reopening-amid-covid-19-pandemicrisk/story?id $=70368692$

[12] https://en.wikipedia.org/wiki/Great Depression

[13] Raef Lawson, "Financial Planning for Reopening Amid Pandemic" in IMA (Institute of Management Accountants), 12 August 2020. Retrieved from https://www.imanet. org/about-ima/news-and-media-relations/ ima-briefing/ima-briefing-list/2020/8/12/ financial-planning-for-reopening?ssopc $=1$

[14] "How restaurants plan to reopen amid the coronavirus pandemic" in $A b s$ NEWS, May 2020. URL: https://aben.ws/3eqhLDl

[15] Bill Hutchinson, "Prospect of reopening amid COVID-19 crisis has some restaurateurs balking" in $A b s$ NEWS, 5 May 2020. URL: https://abcnews.go.com/Business/restaurantsmull-reopening-amid-covid-19-pandemicrisk/story?id=70368692

[16] Ibidem. June

[17] Barbara Feder Ostrov, "Cue the debunking: Two Bakersfield doctors go viral with dubious COVID test conclusions" in Cal Matters, APRIL 27, 2020. Retrieved from https://calmatters.org/health/2020/04/

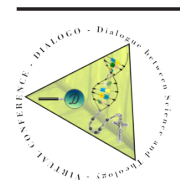


debunking-bakersfield-doctors-covid-spreadconclusions/ accessed on October 5, 2020.

[18] Arjun Walia, "Doctor Claims That Wearing A Mask \& Gloves Is "Not Helping You"", in CE - collective Evolution, April 27, 2020. Retrieved from https://www.collectiveevolution.com/2020/04/27/doctor-claimsthat-wearing-a-mask-gloves-is-not-helpingyou/ accessed on October 5, 2020.

[19] You can watch the full interview here on our member's platform called CETV. Accessed on October 5, 2020.

[20] Anna Magee, "Easy ways to boost your immune system to fight off coronavirus" in The Telegraph, 8 June 2020. URL: https:// www.telegraph.co.uk/health-fitness/body/ easy-ways-boost-immune-system-fightcoronavirus/

[21] Steve Bird, "Lockdown and social distancing could make our immune system weaker, says scientist" in The Telegraph, 27 June 2020. URL: https://www.telegraph. co.uk/news/2020/06/27/lockdown-socialdistancing-could-make-immune-systemweaker-says/

[22] Yusuf Balcı and Güldenur Çetin, "Covid-19 Pandemi Sürecinin Türkiye'de İstihdama Etkileri ve Kamu Açısından Alınması Gereken Tedbirler", IIstanbul Ticaret Üniversitesi Sosyal Bilimler Dergisi, 19 (37), 40-58, p. 40. Retrieved from https://dergipark.org.tr/tr/pub/ iticusbe/issue/55168/752714.

[23] ibid., 42.

[24] Sampath Sowmyanarayan, "Return to business as unusual: Workplace of the future", Retrieved from https://www.verizon. com/about/sites/default/files/Return_To Business_As_Unusua-2020-White-Paper.pdf.

[25] The Malthusian Theory of Population is a theory of exponential population growth and arithmetic food supply growth. Thomas Robert Malthus, an English cleric and scholar, published this theory in his 1798 writings, An Essay on the Principle of Population. Retrieved from https://www.intelligenteconomist.com/ malthusian-theory/

[26] Irwin W. Sherman, Twelve Diseases that Changed Our World, Washington: ASM Press, 2007, p. vii.
[27] Leah Kemp, "How small towns are responding to the global pandemic", June 29, 2020. Retrieved from https://theconversation. com/how-small-towns-are-responding-to-theglobal-pandemic-141016

[28] Harriet Constable, "How do you build a city for a pandemic?", April 27, 2020. Retrieved from https://www.bbc.com/future/ article/20200424-how-do-you-build-a-cityfor-a-pandemic

[29] Emrah Gülsunar "Tarihte Salgınlar, Nüfus Artışı ve Malthusçuluk" [Outbreaks, Population Growth and Malthusianism in History], March 26, 2020. Retrieved from https://daktilo1984.com/yazilar/tarihtesalginlar-nufus-artisi-ve-malthusculuk/

[30] Irwin W. Sherman, Twelve Diseases that Changed Our World, p. viii.

[31] Önder Ergönül, "Pandemi Bize Neler Öğretti?", Hekim Sözü, Sayı 9, MayısHaziran 2020, 16-19, p. 16 Retrieved from https://www.istabip.org.tr/site_icerik/2020/ hekimsozu/sayi9/syf_16.pdf

[32] ibid., p. 17-18.

[33] Guido Silvestri, "10 lessons that the pandemic must have taught us", May 17, 2020. Retrieved from https://www.tellerreport. $\mathrm{com} / \mathrm{news} / 2020-05-17$-coronavirus--thevirologist-silvestri--here-are-the-10-lessonsthat-the-pandemic-must-have-taught-us. SJUidI6CqU.html

[34] Hale Ceren Zeytinoğlu, “Covid-19'a Sosyolojik Bakış", April 28, 2020. Retrieved from https://baslangicnoktasi.org/covid-19asosyolojik-bakis/

[35] Mehmet Karakaş, "Covid-19 Salgınının Çok Boyutlu Sosyolojisi ve Yeni Normal Meselesi", İstanbul Universitesi Sosyoloji Dergisi, 40 (2020): 569-570. Retrieved from https://dergipark.org.tr/tr/download/articlefile/1224651 